\title{
Effect of cholera toxin on the human jejunum
}

\author{
W Petritsch, A J Eherer, U Holzer-Petsche, T Hinterleitner, E Beubler, G J Krejs
}

\begin{abstract}
In order to develop a model for secretory diarrhoea and to confirm the in vitro effects of cholera toxin in man in vivo the effect of intrajejunally administered cholera toxin was investigated in healthy volunteers. An intestinal perfusion technique with an occluding balloon proximal to the infusion site was used. The jejunum was perfused under steady state conditions with a plasma like electrolyte solution containing polyethylene glycol as a non-absorbable volume marker. After two control periods of one hour each, during which water was absorbed at a rate of 104 (14) (mean $(\mathrm{SEM}), \mathrm{n}=15)$ and $94(15) \mathrm{ml} / 30 \mathrm{~cm} / \mathrm{h}$, respectively, three different doses of cholera toxin (6.25 $\mu \mathrm{g}, 12.5 \mu \mathrm{g}, 25 \mu \mathrm{g})$ were administered by bolus into the lumen of the jejunum. Cholera toxin reduced absorption of water and electrolytes progressively over four hours and induced secretion in a dose dependent fashion. In the fourth hour net secretion amounted to 22 (23), 36 (24), and $88(40) \mathrm{ml} / 30 \mathrm{~cm} / \mathrm{h}$ (each $\mathrm{n}=$ five) with doses of $6 \cdot 25,12 \cdot 5$, and $25 \mu \mathrm{g}$ cholera toxin, respectively. The movement of sodium, chloride, and bicarbonate paralleled water movement. Our results suggest that cholera toxin may serve as a secretory model in the human jejunum which might allow testing of new antisecretory agents.

(Gut 1992; 33: 1174-1178)
\end{abstract}

Secretory diarrhoea is an important health problem particularly in developing countries. In order to test new antisecretory agents human models for intestinal secretion need to be established. Because infection with Vibrio cholerae is an important cause of diarrhoea, we decided to use cholera toxin as intestinal secretagogue. Cholera toxin is the enterotoxin of Vibrio cholerae and while causing secretion does not impair glucose dependent sodium absorption in the intestine and does not alter mucosal histology..$^{1-3}$ Earlier studies with chulera toxin in man revealed an increase in stool frequency and

Departments of Internal Medicine and Experimental and Clinical Pharmacology, Karl Franzens University Graz, Austria W Petritsch

A J Eherer

U Holzer-Petsche

T Hinterleitner

E Beubler

G J Krejs

Correspondence to:

Wolfgang Petritsch, MD Department of Internal Medicine, Karl Franzens University, Auenbruggerplat/ 15, A-8036 Graz, Austria.

Accepted for publication

20 January 1992
Quade test: ${ }^{\star}$ significantly different from controls, $\mathrm{p}<0.05$ tsignificantly different from all periods up to second hour after cholera toxin, $\mathrm{p}<0.05$.

Values are means $(\mathrm{SEM}), \mathrm{n}=$ five, $(-)$ denotes absorption

$(+)$ denotes secretion. volume, and intestinal secretion after administration of various preparations of cholera toxin. ${ }^{+5}$ The results of these studies, however, were too variable to lead to the use of cholera toxin as a secretory model. The aims of the present study were to characterise the dose response relationship for cholera toxin after intrajejunal administration, to develop a standardised model of intestinal secretion using an intestinal perfusion technique, and to expand our information on the action of cholera toxin on the human jejunum.

\section{Methods}

\section{SUBJECTS}

Fifteen healthy volunteers (nine men, six women, mean age 28 years, range 22-38) gave written informed consent to participate. None of the subjects was taking any medication. A medical history, electrocardiograph, blood pressure, and standard laboratory findings were obtained before the experiment and were found to be negative or normal. Haematocrit was also obtained 24 hours after the experiment. The study was approved by the Ethics Committee of the University of Graz School of Medicine.

\section{INTESTINAL PERFUSION}

For intestinal perfusion a tube assembly with a proximal occluding balloon was used..$^{6-8}$ The assembly with an outer diameter of $6 \mathrm{~mm}$ and a mercury bag at the tip was placed in the jejunum (infusion site at the ligament of Treitz). The correct position of the tube was confirmed by fluoroscopy. Because in animal studies digestive juices may destroy cholera toxin an occluding balloon proximal to the infusion site was used in order to avoid degradation of cholera toxin by pancreatic enzymes' (E Beubler, unpublished observation). The sampling site was $30 \mathrm{~cm}$ distal to the infusion site. A fourth lumen enabled removal of endogenous secretions proximal to the occluding balloon. Perfusion was started in the morning after a $12-16$ hour fast. A plasma like electrolyte solution (composition in $\mathrm{mmol} / \mathrm{l}$ : $\mathrm{Na}^{+} 135, \mathrm{~K}^{+} 5, \mathrm{Cl}^{-} 110, \mathrm{HCO}_{3}{ }^{-} 30$, and $2 \mathrm{~g} / \mathrm{l}$ polyethylene glycol, mean molecular weight 3350 , as a non-absorbable volume marker) was perfused at $10 \mathrm{ml} /$ minute using a peristaltic pump. The solution was bubbled with a mixture of $95 \% \mathrm{O}_{2}$ and $5 \% \mathrm{CO}_{2}$. A 30 minute equilibration period, during which the samples were discarded was followed by six hours of collection. Collection was performed by hand aspiration at a rate of $1.5 \mathrm{ml} /$ minute using plastic syringes. Collected samples were pooled for each hour. After two control periods of one hour each, $6.25 \mu \mathrm{g}, 12.5 \mu \mathrm{g}$, or $25 \mu \mathrm{g}$ purified cholera toxin (Sigma, Deisenhofen, FRG) was administered intrajejunally as a bolus without interrupt- 
ing the intestinal perfusion. The perfusion was continued for another four hours. The transmural potential difference was measured between a $\mathrm{NaCl}$ filled subcutaneous cannula on one forearm and the luminal contents by means of calomel electrodes, using agar bridges between the cannula and the perfusion tube.

During the entire study the subjects electrocardiograph was displayed on a monitor. Pulse and blood pressure were measured every 20 minutes. After the experiment subjects were asked to drink sufficient liquids and to record frequency of bowel movements and to collect all stools for 24 hours.

ANALYSIS OF SAMPLES AND CALCULATIONS

Intestinal samples were analysed for $\mathrm{Na}^{+}, \mathrm{Cl}^{-}$, $\mathrm{K}^{+}$, and $\mathrm{HCO}_{3}^{-}$(as total $\mathrm{CO}_{2}$ ) using an automatized analyser (Synchron Clinical System CX3, Beckman, USA). Polyethylene glycol was determined according to the method of Hydén. ${ }^{10}$ Absorption and secretion rates in the test segment were calculated from the perfusion rate and the changes in polyethylene glycol and electrolyte concentrations."

\section{STATISTICAL ANALYSIS}

Results are expressed as means (SEM). Statistical analysis was performed using either the parameter free Quade test or the Kruskal-Wallis $\mathrm{H}$-test as was appropriate. A p value of less than 0.05 was regarded as significant:

\section{Results}

EFFECTS OF CHOLERA TOXIN ON NET WATER AND ION TRANSPORT

During the two control periods absorption of water (104 (14) and 94 (15) $\mathrm{ml} / 30 \mathrm{~cm} / \mathrm{h}, \mathrm{n}=15$, respectively) and electrolytes was recorded in all subjects except in one who secreted. Jejunal secretion is, however, known to occasionally occur in healthy subjects. ${ }^{12}$ The secretory response to cholera toxin developed gradually. The first changes of net water and ion transport were observed after the second or third hour after administration of cholera toxin. The maximal effect during the four hour experiment occurred in the fourth hour after administration of cholera toxin (Tables I-V).

Cholera toxin caused dose dependent changes

TABLE II Effect of various doses of cholera toxin $(C T)$ on ne jejunal $\mathrm{Na}^{+}$transport $(\mathrm{mmol} / 30 \mathrm{~cm} / \mathrm{h})$. Cholera toxin was administered after two hours of control perfusion

\begin{tabular}{|c|c|c|c|}
\hline \multirow{2}{*}{$\begin{array}{l}\text { Time }(h) \\
\text { after } C T\end{array}$} & \multicolumn{3}{|c|}{ Intrajejunal dose of $C T$} \\
\hline & $6 \cdot 25 \mu g$ & $12 \cdot 5 \mu \mathrm{g}$ & $25 \mu g$ \\
\hline $\begin{array}{l}\text { Control } \\
\text { Control } \\
1 \\
2 \\
3 \\
4\end{array}$ & $\begin{array}{l}-6 \cdot 3(3 \cdot 8) \\
-4 \cdot 2(3 \cdot 2) \\
-4 \cdot 1(3 \cdot 0) \\
-4 \cdot 0(3 \cdot 0) \\
-0 \cdot 2(4 \cdot 1) \\
+5 \cdot 7(3 \cdot 8)^{\star} \dagger\end{array}$ & $\begin{array}{l}-14.6(1.3) \\
-13.2(1.8) \\
-11.6(1.4) \\
-7.8(1.8)^{\star} \\
+2.5(3.0)^{\star} \\
+6.8(3.4)^{\star} \dagger\end{array}$ & $\begin{array}{l}-16.4(3.3) \\
-16.5(2 \cdot 4) \\
-15.1(2.8) \\
-7.6(4 \cdot 4)^{\star} \\
-11.2(7.0)^{\star} \\
+17.0(5 \cdot 7)^{\star} \dagger\end{array}$ \\
\hline
\end{tabular}

Quade test: * significantly different from controls, $\mathrm{p}<0.05$;

tsignificantly different from all periods up to second hour after cholera toxin, $\mathrm{p}<0.05$

Values are means (SEM), $\mathrm{n}=$ five, $(-)$ denotes absorption,

$(+)$ denotes secretion.
TABLE III Effect of various doses of cholera toxin $(C T)$ on net jejunal $\mathrm{Cl}^{-}$transport $(\mathrm{mmol} / 30 \mathrm{~cm} / \mathrm{h})$. Cholera toxin was administered as a bolus after two hours of control perfusion

\begin{tabular}{|c|c|c|c|}
\hline \multirow{2}{*}{$\begin{array}{l}\text { Time }(h) \\
\text { after } C T\end{array}$} & \multicolumn{3}{|c|}{ Intrajejunal dose of $C T$} \\
\hline & $6.25 \mu g$ & $12 \cdot 5 \mu \mathrm{g}$ & $25 \mu g$ \\
\hline $\begin{array}{l}\text { Control } \\
\text { Control } \\
1 \\
2 \\
3 \\
4\end{array}$ & $\begin{array}{l}-1.3(2.9) \\
+0.6(2 \cdot 1) \\
+0.7(1.6) \\
+0.9(2.3) \\
+2.9(2.8)^{\star} \\
+6.8(2.5)^{\star} \dagger\end{array}$ & $\begin{array}{l}-5 \cdot 7(1 \cdot 4) \\
-4 \cdot 8(1 \cdot 5) \\
-5 \cdot 1(0 \cdot 9) \\
-3 \cdot 3(1 \cdot 1) \\
+2 \cdot 3(1 \cdot 1)^{\star} \\
+4 \cdot 8(1 \cdot 8)^{\star} \dagger\end{array}$ & $\begin{array}{l}-7 \cdot 8(2 \cdot 9) \\
-7.6(2 \cdot 3) \\
-6.9(2 \cdot 0) \\
-2.3(2 \cdot 4)^{\star} \\
+8.7(5 \cdot 3)^{\star} \\
+14.6(4.8)^{\star} \dagger\end{array}$ \\
\hline
\end{tabular}

Quade test: *significantly different from controls, $\mathrm{p}<0.05$; †significantly different from all periods up to second hour after cholera toxin, $\mathrm{p}<0.05$.

Values are means $($ SEM $), n=$ five,$(-)$ denotes absorption, $(+)$ denotes secretion.

TABLE IV Effect of various doses of cholera toxin $(C T)$ on net jejunal $\mathrm{K}^{+}$transport $(\mathrm{mmol} / 30 \mathrm{~cm} / \mathrm{h})$. Cholera toxin was administered as a bolus after two hours of control perfusion

\begin{tabular}{|c|c|c|c|}
\hline \multirow{2}{*}{$\begin{array}{l}\text { Time }(h) \\
\text { after } C T\end{array}$} & \multicolumn{3}{|c|}{ Intrajejunal dose of $C T$} \\
\hline & $6 \cdot 25 \mu g$ & $12 \cdot 5 \mu \mathrm{g}$ & $25 \mu g$ \\
\hline $\begin{array}{l}\text { Control } \\
\text { Control } \\
1 \\
2 \\
3 \\
4\end{array}$ & $\begin{array}{l}-0.34(0.13) \\
-0.30(0.10) \\
-0.30(0.11) \\
-0.36(0.11) \\
-0.30(0.13) \\
-0.14(0.10)\end{array}$ & $\begin{array}{l}-0.76(0.04) \\
-0.72(0.07) \\
-0.62(0.06) \\
-0.48(0.07)^{\star} \\
-0.16(0.12)^{\star} \\
-0.06(0.11)^{\star} \dagger\end{array}$ & $\begin{array}{l}-0.76(0.11) \\
-0.82(0.10) \\
-0.76(0.14) \\
-0.56(0.21)^{\star} \\
+0.04(0.31)^{\star} \\
+0.20(0.26)^{\star}\end{array}$ \\
\hline
\end{tabular}

Quade test: *significantly different from controls, $\mathrm{p}<0.05$; tsignificantly different from all periods up to second hour after cholera toxin, $\mathrm{p}<0.05$

Values are means (SEM), $\mathrm{n}=$ five, $(-)$ denotes absorption, Values are means $(\mathrm{SEM})$
$(+)$ denotes secretion.

TABLE v Effect of various doses of cholera toxin $(C T)$ on ne jejunal $\mathrm{HCO}_{3}{ }^{-}$movement $(\mathrm{mmol} / 30 \mathrm{~cm} / \mathrm{h})$. Cholera toxin was administered as a bolus after two hours of control perfusion

\begin{tabular}{llll}
\hline \multirow{4}{*}{$\begin{array}{l}\text { Time }(h) \\
\text { after } C T\end{array}$} & \multicolumn{4}{l}{ Intrajejunal dose of $C T$} \\
\cline { 2 - 4 } & $6 \cdot 25 \mu \mathrm{g}$ & $12 \cdot 5 \mu \mathrm{g}$ & $25 \mu \mathrm{g}$ \\
\hline Control & $-4 \cdot 6(0 \cdot 7)$ & $-8 \cdot 8(0 \cdot 4)$ & $-8 \cdot 8(1 \cdot 3)$ \\
Control & $-4 \cdot 0(1 \cdot 0)$ & $-8 \cdot 2(0 \cdot 5)$ & $-8 \cdot 9(1 \cdot 3)$ \\
1 & $-4 \cdot 1(1 \cdot 1)$ & $-7 \cdot 0(1 \cdot 0)$ & $-8 \cdot 5(2 \cdot 0)$ \\
2 & $-3 \cdot 9(1 \cdot 0)$ & $-4 \cdot 2(1 \cdot 4)^{\star}$ & $-5 \cdot 3(2 \cdot 5)$ \\
3 & $-2 \cdot 1(1 \cdot 6)$ & $-0 \cdot 2(2 \cdot)^{\star}$ & $+1 \cdot 2(3 \cdot 2)^{\star}$ \\
4 & $-0 \cdot 1(1 \cdot 6)^{\star} \dagger$ & $+1 \cdot 8(1 \cdot 8)^{\star} \dagger$ & $+2 \cdot 5(2 \cdot 3)^{\star} \dagger$ \\
\hline
\end{tabular}

Quade test: *significantly different from controls, $\mathrm{p}<0 \cdot 05$; tsignificantly different from all periods up to second hour after cholera toxin, $\mathrm{p}<0.05$

Values are means $(\mathrm{SEM}), \mathrm{n}=$ five, $(-)$ denotes absorption, $(+)$ denotes secretion.

TABLE VI Effect of various doses of cholera toxin (CT) on stool frequency and weight $(\mathrm{g})$ within 24 hours after the experiment

\begin{tabular}{lclc}
\hline \multicolumn{4}{c}{ Intrajejunal dose of $C T$} \\
\cline { 2 - 4 } & $6 \cdot 25 \mu g$ & $12 \cdot 5 \mu g$ & $25 \mu g$ \\
\hline $\begin{array}{c}\text { Frequency of } \\
\text { liquid bowel } \\
\text { movements }\end{array}$ & $5(1)[5]$ & $8(3)[5]$ & $6(2)[5]$ \\
$\begin{array}{c}\text { Stool weight }(g) \\
\text { g }\end{array}$ & $1000(300)[5]$ & $2017(109)[3]$ & $1528(405)[5]$ \\
\hline
\end{tabular}

Values are mean (SEM), number of subjects from which results are available are given in square brackets.

in net fluid and ion transport (Figure). Measurements of water as well as of $\mathrm{Na}^{+}$and $\mathrm{Cl}^{-}$revealed significant changes toward secretion induced by all three doses of cholera toxin (Tables I-III). Net movement of water was significantly differ- 

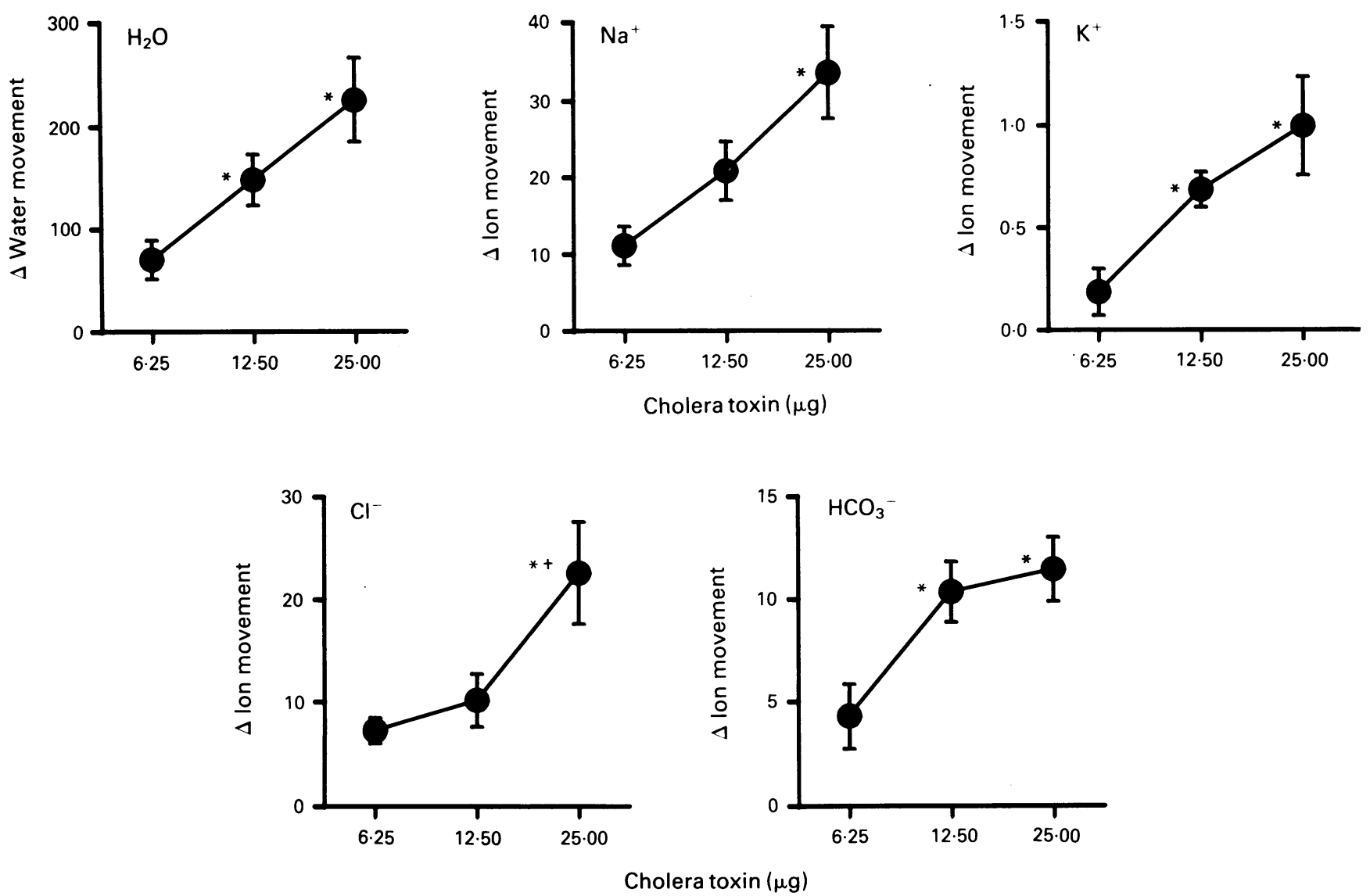

Dose response relationship for intrajejunal cholera toxin $(C T)$ on $\Delta$ water and ion movement ( $m l$ or mmol/30 cm/h) during the fourth hour after administration of the enterotoxin. ( $\triangle:$ net movement in the fourth hour minus basal movement; mean $(S E M)$, five).

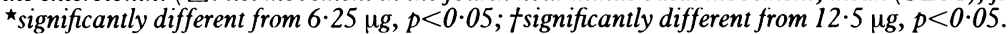

ent from zero (secretion) when the $25 \mu \mathrm{g}$ dose of cholera toxin was administered. Net $\mathrm{K}^{+}$transport was not changed by the lowest dose of cholera toxin $(6 \cdot 25 \mu \mathrm{g})$. Net $\mathrm{K}^{+}$absorption was significantly decreased by $12 \cdot 5 \mu \mathrm{g}$ cholera toxin, and only the highest dose $(25 \mu \mathrm{g})$ caused net secretion (Table IV). $\mathrm{HCO}_{3}$ absorption was reduced by $6.25 \mu \mathrm{g}$ cholera toxin and changed to secretion by the higher doses (Table V). Cholera toxin caused no change in potential difference in any of the groups.

\section{CLINICAL EFFECTS}

Blood pressure and heart rate did not change during the course of the studies. Cholera toxin did not cause nausea or vomiting. Stool volume and frequency (Table VI) increased after all doses of cholera toxin to a higher degree than might be expectred after intestinal perfusion studies using balanced electrolyte solutions. Only one subject who had received 6.25 $\mu \mathrm{g}$ cholera toxin observed no increase in stool frequency, however, in this case only decreased absorption and not secretion was observed in the test segment. In two subjects receiving $25 \mu \mathrm{g}$ cholera toxin and in one receiving $12.5 \mu \mathrm{g}$ cholera toxin liquid bowel movements continued up to 48 hours but caused no serious inconvenience. In the other subjects liquid bowel movements stopped after 24 hours. After 24 hours haematocrit values were within the normal range (44 (1)\%).

\section{Discussion}

In this study we developed a model for intestinal secretion in man using cholera toxin as a secretagogue and measured the changes in jejunal water and electrolyte movement in response to cholera toxin. Our experiments showed a significant dose dependent change from absorption toward secretion of water and electrolytes. We found a maximum of fluid secretion of $88 \mathrm{ml} / 30 \mathrm{~cm} / \mathrm{h}$ with a dose of $25 \mu \mathrm{g}$ cholera toxin four hours after exposure to the toxin. Jejunal perfusion studies in patients with acute cholera studied by others showed a wide range of net fluid secretion from 2 to $326 \mathrm{ml} / 30 \mathrm{~cm} / \mathrm{h}$ with corresponding movements of $\mathrm{Na}^{+}, \mathrm{K}^{+}, \mathrm{Cl}^{-}$, and $\mathrm{HCO}_{3}{ }^{-}$into the lumen. ${ }^{13}$ Thus, in the present study we induced secretion in the test segment which lies well within the range of secretion observed with naturally occurring cholera.

When 'cholera' is considered for experiments in healthy subjects the most important question to answer concerns safety. As opposed to natural cholera we used a single dose of purified cholera toxin but did not administer Vibrio cholerae, which would produce cholera toxin for several days. Thus, the expected time for intestinal secretion was limited. Moreover, only a very small segment of jejunum was exposed to the full dose of cholera toxin and because of the rapid binding of the toxin to the mucosa it was presumed that cholera toxin was not available in the distal small bowel to induce secretion. Some liquid bowel movements are expected after many 
types of intestinal perfusion studies and in most of the subjects in this study liquid bowel movements had stopped after 24 hours. Only in three subjects liquid bowel movements continued up to 48 hours, but in no subject did this cause any serious inconvenience. During the perfusion studies we observed no change in blood pressure or heart rate. After the end of the study the volunteers were asked to drink 1.5-2 1 of an ora rehydration solution over the next 24 hours, but most of the subjects preferred other liquids. A normal haematocrit after 24 hours was present in all subjects and indicated either sufficient oral liquid intake or insignificant fluid loss. We conclude that a bolus of cholera toxin of 6.25 to $25 \mu \mathrm{g}$ can be used safely as an intestinal secretagogue when the described precautions are being taken.

In addition to the secretion of $\mathrm{Na}^{+}$and $\mathrm{Cl}^{-}$we found marked secretion of $\mathrm{HCO}_{3}{ }^{-}$into the jejunum, thus confirming previous in vivo studies in animals. ${ }^{2+18}$ In experimental animals cholera toxin induces marked secretion of fluid and electrolytes. Where $\mathrm{HCO}_{3}{ }^{-}$was also measured net secretion was observed. ${ }^{21+16}$ This is in contrast with in vitro studies in ileal mucosa using short circuit current conditions where no significant changes of $\mathrm{HCO}_{3}{ }^{-}$fluxes were found. ${ }^{19}$ To our knowledge there are no in vitro studies using jejunal mucosa. The different findings in vitro and in vivo underline the importance of in vivo studies in man.

Normally $\mathrm{HCO}_{3}{ }^{-}$is absorbed by the jejunum. The absorption is thought to result from $\mathrm{a} \mathrm{Na}^{+} /$ $\mathrm{H}^{+}$exchange mechanism whereby $\mathrm{H}^{+}$is secreted into the lumen in exchange for $\mathrm{Na}^{+} .{ }^{20}$ Thus, in addition to the $\mathrm{Cl}^{-}$and $\mathrm{Na}^{+}$transport mechanisms the putative jejunal $\mathrm{Na}^{+} / \mathrm{H}^{+}$ exchange many also be inhibited by cholera toxin. The secretion of $\mathrm{HCO}_{3}{ }^{-}$is of clinical importance as the high amount of $\mathrm{HCO}_{3}{ }^{-}$in cholera stools may lead to metabolic acidosis when diarrhoea continues for several days. Potential difference did not change during the observed effects in ion transport in our study. Although a change to lumen negativity would be expected with active anion secretion our results are in accordance with those of Sachar, who found marked accumulation of water and electrolytes in the intestine of patients with cholera without alteration of the transmural potential difference in the small bowel. ${ }^{21}$

We found no correlation between net secretion of water and electrolytes in the test segment and stool weight while liquid bowel movements were present after the experiment. Such a lack of correlation was also observed by Levin after oral administration of $5 \mu \mathrm{g}$ purified cholera toxin to healthy volunteers. ${ }^{5}$ The amount of diarrhoea in acute cholera infection is also very variable. Many cases are mild and cannot be distinguished from viral gastroenteritis. When cholera toxin is used as secretagogue a variable response in stool volume should thus be expected.

In our experiments the secretory effect of cholera toxin began in the second hour after administration of the toxin. The observed maximal effect was reached in the fourth hour although we do not know whether secretion would still have been higher in the fifth or sixth hour. For reasons of compliance it was not possible to plan for longer experiments (our experiments lasted approximately eight hours from start to end). This delayed effect of cholera toxin is well known from animal experiments. ${ }^{1} 6^{1722}$ It might be explained by the fact that the toxin is effective from the luminal side and binds irreversibly to a particular membrane receptor. It probably takes time to enter the cell and to activate a cascade of intracellular mechanisms leading to secretion of water and electrolytes. Carpenter assumed that increased fluid secretion began shortly after toxin administration but that net fluid production was not observed until the rate of secretion exceeded the rate of absorption. ${ }^{22}$ The secretory effect of cholera toxin in our study probably continued for hours as evidenced by the stool output after the experiment. Recovery occurs when the affected intestinal epithelial cells on the villi are replaced by new enterocytes moving up from the crypts. $^{3}$

The late onset and long duration of secretion and the induction of significant $\mathrm{HCO}_{3}{ }^{-}$secretion are the most important differences between the effect of cholera toxin and other secretagogues such as vasoactive intestinal polypeptide or prostaglandin. Intravenously administered vasoactive intestinal polypeptide instantly changed absorption to secretion and the effect stopped after the end of the infusion. No subject developed diarrhoea, and even at the highest dose tested of $400 \mathrm{pmol}$ vasoactive intestinal polypeptide $/ \mathrm{kg} / \mathrm{h}$ only reduced absorption or a low rate of secretion of water and electrolytes was observed. ${ }^{23}$ There was only a slight but statistically not significant decrease in $\mathrm{HCO}_{3}$ absorption caused by vasoactive intestinal polypeptide..$^{23}$ This is in contrast to our results where cholera toxin induced marked secretion of $\mathrm{HCO}_{3}{ }^{-}$. Intrajejunally administered prostaglandin $E_{1}$ at a dose of $0.9 \mu \mathrm{g} / \mathrm{kg} / \mathrm{min}$ induced marked secretion of water and electrolytes beginning after 30 minutes and ending within 60 minutes after prostaglandin infusion. ${ }^{25} \mathrm{~A}$ dose of $5 \mu \mathrm{mol} / \mathrm{l}$ prostaglandin $\mathrm{E}_{2}$ tested in our laboratory induced secretion of water, $\mathrm{Na}^{+}$and $\mathrm{Cl}^{-}$ similar to $25 \mu \mathrm{g}$ cholera toxin, but without affecting $\mathrm{HCO}_{3}{ }^{-}$absorption. ${ }^{26}$ One might speculate that $\mathrm{HCO}_{3}{ }^{-}$secretion is mainly initiated by certain agents such as toxins from the luminal side, whereas hormones or prostaglandins, which normally act from the basolateral membrane of enterocytes, do not significantly affect $\mathrm{HCO}_{3}{ }^{-}$transport in man in vivo. Another marked difference between the effects of cholera toxin and vasoactive intestinal polypeptide or prostaglandins is that secretion stopped promptly after prostaglandin or vasoactive intestinal polypeptide infusion. The latency of the response to cholera toxin as well as its prolonged effect depend on its mode of action as mentioned above. In contrast with cholera toxin, vasoactive intestinal polypeptide and prostaglandins are bound reversibly, and act only as long as their levels in plasma or in the intestinal lumen are raised.

In conclusion, our study shows a significant, dose dependent change from absorption to secretion of water and electrolytes in the human 
jejunum induced by cholera toxin. This model is expected to lend itself to study the effectiveness of antisecretory agents in the human intestine.

Supported by Austrian Scientific Research Foundation Grant No P7741. The authors thank Ms S Hugill and Mr K Fürstauer for their excellent technical assistance.

1 Field M, Fromm D, Al-awaqati Q, Greenough WB. Effect of cholera enterotoxin on ion transport across isolated ileal mucosa. F Clin Invest 1972; 51: 796-804.

2 Tantisira MH, Fändriks L, Jönsson C, Jodal M, Lundgren O. Studies of cholera toxin-induced changes of alkaline secretion and transepithelial potential difference in the rat intestine in vivo. Acta Physiol Scand 1990; 138: 75-84.

3 Finkelstein RA. Cholera, the cholera enterotoxins, and the cholera enterotoxin-related enterotoxin family. In: Owen $\mathrm{P}$, Fost TJ, Immunchemical and molecular gemeic anc of bacterial pathogens. Amsterdam: Elsevier Science of bacterial pathogens. A

4 Benyajati C. Experimental cholera in human. BMF 1966; 1 : $140-2$.

5 Levin M, Kaper JB, Black RE, Clements ML. New knowledge on pathogenesis of bacterial enteric infection as applie to vaccine development. Microbiol Rev 1983; 47: 510-50.

6 Sladen GE, Dawson AM. Further studies on the perfusion method for measuring intestinal absorption in man: The effects of a proximal occlusive balloon and a mixing segment Gut 1970; 11: 947-54.

7 Modigliani R, Rambaud JC, Bernier JJ. The method of intraluminal perfusion of the human small intestine. Digestion 1973; 9: 176-92.

8 Modigliani R, Rambaud JC, Bernier JJ. Validation of the use of a tube with a proximal occlusive balloon for measuremen of a tube with a proximal occlusive balloon for measurement
of intestinal absorption in man. Dig Dis Sci 1978; 23: 720-2.

9 Aziz KMS, Mohsin AKM, Hare WK, Phillips RA. Using the rat as a cholera 'model'. Nature 1968; 220: 814-5.

10 Hydén SA. A turbidimetric method for the determination of higher polyethylene glycols in biological materials. Ann $R$ Agr Coll Sweden 1956; 22: 139-45.

11 Modigliani R, Bernier JJ. Absorption of glucose, sodium and water by the human jejunum studied by intestinal perfusion with a proximal occluding balloon and at variable flow rats. Gut 1971; 12: 184-93.

12 Davis GR, Carol SA, Morawski S, Fordtran JS. Active chloride secretion in the normal human jejunum. $\mathcal{f}$ Clin Invest 1980; 66: 1326-33.
13 Banwell JG, Pierce NF, Mitra RC, Brigham KL, Caranasos GJ, Keimowitz RI, et al. Intestinal fluid and electrolyte transport in human cholera. $\mathcal{F}$ Clin Invest 1970; 49: 183-95.

14 Carpenter CCJ, Sack RB, Feeley JC, Steenberg RW. Site and characteristics of electrolyte loss and effect of intralumina glucose in experimental canine cholera. $\mathcal{F}$ Clin Invest 1968 47: $1210-20$.

15 Leitch GJ, Burrows W. Experimental cholera in the rabbit ligated intestine: ion and water accumulation in the duodenum, ileum and colon. 7 Infect Dis 1968; 118: 349-59.

16 Krejs GJ, Barkley RM, Read NW, Fordtran JS. Intestinal secretion induced by vasoactive intestinal polypeptide. A comparison with cholera toxin in the canine jejunum in vivo. comparison with cholera toxin in

17 Beubler E, Kollar G, Saria A, Bukhave K, Rask-Madsen J. Involvement of 5-hydroxytryptamine, prostaglandin $E_{2}$ and cyclic adenosine monophosphate in cholera toxin-induced fluid secretion in the small intestine of rat in vivo. Gastroenterology 1989; 96: 368-76.

18 Larosa CA, Sherlock D, Kimura K, Pimpl W, Money SR, Jaffe BM. The role of serotonin in the canine secretory response to cholera toxin in vivo. $\mathcal{F}$ Pharmacol Exp Ther 1989; 251: 71-6.

19 Powell DW, Binder HJ, Curran PF. Active electrolyte secretion stimulated by choleragen in rabbit ileum in vitro. $A m \mathcal{F}$ Physiol 1973; 225: 781-7.

20 Turnberg LA, Fordtran JS, Carter W, Rector JR. Mechanism of bicarbonate absorption and its relationship to sodium transport in the human jejunum $\mathcal{F}$ Clin Invest 1970;49. $548-56$

21 Sachar DB, Taylor JO, Saha JR, Phillips RA. Intestina transmural electric potential and its response to glucose in acute and convalescent cholera. Gastroenterology 1969; 56 512-21.

22 Carpenter CCJ, Greenough WB III. Response of the canine duodenum to intraluminal challenge with cholera exotoxin. 7 Clin Invest 1968; 47: 2600-7.

23 Krejs GJ, Fordtran JS, Bloom SR, Fahrenkrug J Schaffalitzky de Muckadell OB, Fischer JE, et al. Effects of VIP infusion on water and ion transport in the human jejunum. Gastroenterology 1980; 78: 722-7.

$24 \mathrm{Krejs}$ GJ. Effect of somatostatin infusion on VIP-induced transport changes in the human jejunum. Peptides $1984 ; 5$ $271-6$.

25 Matuchansky C, Mary JY, Bernier JJ. Further studies on prostaglandin $E_{1}$-induced jejunal secretion of water and electrolytes in man, with special reference to the influence of ethacrynic acid, furosemide and aspirin. Gastroenterology 1976; 71: 274-81

26 Holzer-Petsche U, Petritsch W, Hinterleitner T, Eherer A, Sperk G, Krejs GJ. Effect of neuropeptide Y on jejunal water and ion transport in man. Gastroenterology 1991; 101: 325-30. 